\title{
Functional characterization of mango seed starch (Mangifera indica l.)
}

\author{
Caracterização funcional do amido de semente de manga (Mangifera indica l.) \\ Caracterización funcional del almidón extraído de la semilla de mango (Mangifera indica l.)
}

\author{
Joiciana Cardoso Arruda de Souza \\ ORCID: https://orcid.org/0000-0002-9807-8425 \\ Universidade Federal da Bahia, Brazil \\ E-mail: joicianacardoso@gmail.com \\ Jéssica Franco Freitas Macena \\ ORCID: https://orcid.org/0000-0003-2138-4333 \\ Universidade Federal da Bahia, Brazil \\ E-mail: jel_freitas@hotmail.com \\ Ivo Henrique Pinto Andrade \\ ORCID: https://orcid.org/0000-0002-5562-5943 \\ Universidade Federal da Bahia, Brazil \\ E-mail: ivo_henriquee@ @otmail.com \\ Geany Peruch Camilloto \\ ORCID: https://orcid.org/0000-0002-3924-7823 \\ Universidade Estadual de Feira de Santana, Brazil \\ E-mail: geanyperuch@yahoo.com.br \\ Renato Souza Cruz \\ ORCID: https://orcid.org/0000-0002-4503-1631 \\ Universidade Estadual de Feira de Santana, Brazil \\ E-mail: cruz.rs@uefs.br
}

\begin{abstract}
Mango agribusiness is an expanding activity in Brazil and produces a large volume of waste that are not reused. Mango seeds are one of the residues from fruit processing, and are a potential starch source. In the food industry, starch is used as a functional ingredient, allowing the preservation of important characteristics of foods. The objectives of this study were to extract starch from mango seed, and to characterize it in terms of its physicochemical, technological and rheological properties. Starch extraction involved washing, cutting, and milling the mango seeds. The extraction yield was $53.89 \%$ and the starch granules presented spherical to irregular ellipsoidal shapes with superficial grooves and average size of $20 \mu \mathrm{m}$. It had an initial paste temperature of $75.3{ }^{\circ} \mathrm{C}$ and a maximum viscosity of $706 \mathrm{BU}$ at $88.1^{\circ} \mathrm{C}$. The rate of syneresis, $1.51 \%$, was considered low, which indicates a starch with good stability at low temperatures. In the texture profile it was found that there was a significant difference $(\mathrm{p} \leq 0.05)$ in the texture profile of gels with sodium chloride, sucrose and citric acid added. The gel with emulsifier showed no significant difference in any of the parameters analyzed (hardness, cohesiveness and gumminess). The properties of the starch indicated great potential for use in food products.
\end{abstract}

Keywords: Agroindustry; Waste; Starch; Additive; Paste properties.

\section{Resumo}

O agronegócio da manga é uma atividade em expansão no Brasil e produz um grande volume de resíduos que não são reaproveitados. As sementes da manga são um dos resíduos provenientes do processamento da fruta, e são uma fonte amilácea em potencial. $\mathrm{Na}$ indústria de alimentos, o amido é utilizado como ingrediente funcional, permitindo a preservação de características importantes dos alimentos. Os objetivos deste estudo foram extrair o amido do caroço da manga e caracterizá-lo quanto às suas propriedades físico-químicas, tecnológicas e reológicas. A extração do amido envolveu a lavagem, cortes, e moagem das sementes da manga. O rendimento de extração foi de $53.89 \%$ e os grânulos de amido apresentaram formas elipsoidais esféricas a irregulares com sulcos superficiais e tamanho médio de $20 \mu \mathrm{m}$. Tinha uma temperatura inicial da pasta de $75.3{ }^{\circ} \mathrm{C}$ e uma viscosidade máxima de $706 \mathrm{BU}$ a $88.1{ }^{\circ} \mathrm{C}$. A taxa de sinérese foi de $1.51 \%$, o que indica um amido com boa estabilidade a baixas temperaturas. No perfil de textura, foi encontrada diferença significativa $(\mathrm{p} \leq 0.05)$ no perfil de textura dos géis com adição de cloreto de sódio, sacarose e ácido cítrico. $\mathrm{O}$ gel com emulsificante não apresentou diferença significativa em nenhum dos parâmetros analisados (dureza, coesividade e goma). As propriedades do amido indicaram grande potencial para uso em produtos alimentícios.

Palavras-chave: Agroindústria; Resíduo; Amido; Aditivo; Propriedades de pasta. 


\section{Resumen}

El agronegocio de mango es una actividad en expansión en Brasil y produce un gran volumen de residuos que no son aprovechados. El cuesco de mango es uno de los residuos oriundos del procesamiento de la fruta, y es una fuente amilácea en potencial. La industria alimentaria, utiliza el almidón como insumo funcional, lo que permite la conservación de importantes características de los alimentos. Los objetivos de este estudio fueron extraer el almidón del cuesco de mango y caracterizarlo cuanto a sus propriedades fisicoquimicas, tecnológicas y reológicas. La extracción de almidón implicó lavado, corte y molienda del cuesco de mango. El rendimiento de la extracción fue de $53.89 \%$ y los gránulos del almidón presentaron formas elipsoidales de esféricas a irregulares con surcos superficiales y tamaño medio de $20 \mu \mathrm{m}$. Tenía una temperatura inicial de la pasta de $75.3{ }^{\circ} \mathrm{C}$ y una viscosidad máxima de $706 \mathrm{BU}$ a $88.1^{\circ} \mathrm{C}$. La tasa de sinérese fue del $1.51 \%$ lo que indica un almidón con buena estabilidad a bajas temperaturas. En el perfil de textura, fue encontrada diferencias significativas $(p \leq 0.05)$ en el perfil de texturas de los geles con adición de cloruro de sodio, sacarosa y ácido cítrico. El gel con emulsificante no presentó diferencias significativas en ninguno de los parámetros analizados (dureza, cohesividad y goma). Las propiedades del almidón indicaron un gran potencial para su uso en productos alimentícios.

Palabras clave: Agroindustria; Residuo; Almidón; Aditivo; Textura.

\section{Introduction}

Considered an energy reserve of vegetables, starch can be found in seeds, roots and tubers. According to Oliveira Filho and Mancim (2009) starch is the unique polysaccharide produced in small individual aggregates, called granules and, as such, have a different size and shape for each species (Do Prado Cordoba et al., 2016). Starch can contribute greatly to the texture and properties of many foods and can be used as a thickener, colloidal stabilizer, gelling agent, substance retainer and viscosity agent (Do Prado Cordoba et al., 2016).

Mango (Mangifera indica L.), belonging to the Anacardiaceae family and with a large amount of pulp and low acidity, has consumer-friendly sensory characteristics such as taste and aroma. In the food industry, the largest use of fruit is in the form of whole juice or frozen pulp, which is the raw material for the production of other products such as sweets, jellies, juices and nectars, besides being added to ice cream, mixtures of juices, liqueurs and other products (Mendes et al., 2015).

According to Embrapa - Empresa de Prasileira (http://www.cnpmf.embrapa.br/Base_de_Dados/index_pdf/dados/brasil/manga/b1_manga.pdf,), 1.414 .338 tons of mango were produced in Brazil in 2019. The processing of the mango produces the disposal of the core and peels, generating a waste that corresponds to 28 to $43 \%$ of the total weight of the fruit (Azevêdo et al., 2008). Currently, due to environmental, sustainability and eco-efficiency issues, attention is being drawn to the use of agro-industrial waste as a potential source of high added value compounds that can be used in food. The starch present in mango seed can be included in a monogastric diet, including humans, as an ingredient in jellies, jams, ice cream and others, without causing adverse effects (Vieira et al., 2009).

In this context, new studies that characterize nonconventional sources are necessary as various sectors are looking to use native starch in their products that have similar desirable characteristics to modified starch, such as higher mass clarity, high temperature resistance, low viscosity at low temperatures and higher resistance to acidity.

\section{Materials and Methods}

\subsection{Starch Extraction}

Starch from mango seed (variety Tommy Atkins) was obtained by the method described in Macena et al. (2020). The seeds were washed and cut into small pieces, crushed in a $900 \mathrm{~W}$ power household blender for 10 min with $0.2 \%$ (v/v) sodium metabisulfite solution. The material obtained was dispersed in distilled water and filtered on voile fabric and the retained bagasse washed to remove adhering starch. Then, decantation was performed for $24 \mathrm{~h}$ under refrigeration, and was subjected to three resuspension intervals in distilled water of $1 \mathrm{~h}$ each. It was then centrifuged (Excelsa 4, model MOD. $280 \mathrm{R})$ at $1105 \times \mathrm{g}$ for 12 min. The supernatant was discarded and the decant was retained. The residue obtained was dried in a drying oven (Marconi, 
model MA 033$)$ at $40{ }^{\circ} \mathrm{C}$ for $12 \mathrm{~h}$. The dried starch was ground to obtain a powder $(0.250 \mathrm{~mm})$ and stored in a clean dry container at room temperature $\left(25^{\circ} \mathrm{C}\right)$.

The yield (RSA) of mango seed starch (MSS) was obtained according to Equation 1, where (me) is the dry starch mass after extraction and (mc) the shelled seed mass.

$$
\operatorname{RSA}\left(\mathrm{g} \times 100 \mathrm{~g}^{-1}\right)=\frac{m e(\mathrm{~g})}{m c(\mathrm{~g})} \times 100
$$

\subsection{Physicochemical characterization of starch from mango seeds}

The physicochemical characterization of starch was performed according to the AOAC (2005). Where the following analyzes were performed in three replicates: Moisture analyzes at $105^{\circ} \mathrm{C}$ to constant weight; total proteins by the Kjeldahl method $(\mathrm{N} \times 6.25)$; Muffle incineration ash at $550{ }^{\circ} \mathrm{C}$; total lipids by the Bligh \& Dyer method. Apparent amylose content was determined by spectrophotometer (BIOSPECTRO SP-220) according to the methodology of International Organization for Standardization (1987) adapted by Castanha et al. (2018).

\subsection{Morphological characteristics of mango seed starch granules}

Size analysis was performed using the Mastersizer, model 3000-Malvern, equipment used for micro range size analysis. D10, D50, D90 are provided which represent the size ranges of 10\%, 50\% and $90 \%$ of the particle population.

For the shape analysis, the Scanning Electron Microscopy (SEM) technique was used. The starch granules were placed on double-sided tape and coated with gold, a process denominated metallization, in a DENTON VACUUM metallizer, DESCK $\mathrm{V}$ model. The shape of the mango seed starch granules was analyzed by JEOL JSM-6390LV scanning electron microscope with $10 \mathrm{kV}$ voltage.

The absolute density (particle density) of the starch granules was determined using a pycnometer by the displacement of xylene at $30^{\circ} \mathrm{C}$, according to Schoch and Leach (1964).

\subsection{X-ray Diffraction (XRD)}

The X-ray diffraction pattern was obtained from starch as a powder containing approximately $16 \%$ moisture. The operating parameters of the Shimadzu X-ray Diffractometer, model XRD-6000 with graphite monochromator were: CuK radiation $(\lambda=1.5405 \AA)$, at a power of $40 \mathrm{kV}, 30 \mathrm{~mA}$, with a scanning speed of $1.2^{\circ} \cdot \mathrm{min}-1$, under an angle of $2 \theta$, ranging from $3-35^{\circ}$, and intervals of $0.02^{\circ}$.

The degree of crystallinity was estimated quantitatively, following the method described in the literature (Andrade et al., 2014; Beninca et al., 2013; Colman et al., 2014), by equation 2 below:

$$
\operatorname{Dc}(\%)=\frac{\mathrm{Ac}}{(\mathrm{Ac}+\mathrm{Aa})} \times 100
$$

Where Dc is the degree of crystallinity, Ac is the crystalline area on the X-ray diffractogram, and Aa is the amorphous area on the X-ray diffractogram.

\subsection{Paste clarity and tendency to retrograde}

Paste clarity and tendency to retrograde were evaluated by measuring the transmittance percentage $(\% \mathrm{~T})$ at $650 \mathrm{~nm}$ in a spectrophotometer (BIOSPECTRO SP-220) as described by Lawal and Adebowale (2005). The suspensions were stored in a 
refrigerator at $4{ }^{\circ} \mathrm{C}$ for $24 \mathrm{~h}$ for nucleation, and then stored at $30{ }^{\circ} \mathrm{C}$ for 9 days, to monitor the tendency of the samples to retrograde, and their absorbance was determined on days 1, 2, 3, 5, 7, 8 and 9 of storage.

\subsection{Swelling Power (SP) and Solubility Index (SI)}

The swelling power of MSS was determined according to the adapted method described by Adebowale et al. (2002). Three $8 \mathrm{~g}$ starch samples were each weighed in pre-weighed centrifuge tubes and $100 \mathrm{ml}$ distilled water was added. The suspensions were placed in a water bath at different temperatures $\left(50,60,70,80\right.$ and $90{ }^{\circ} \mathrm{C}$ ) for $30 \mathrm{~min}$, agitated every $5 \mathrm{~min}$ and centrifuged at $1306 \times \mathrm{g}$ (Excelsa 4, model MOD. 280R) for $5 \mathrm{~min}$. A $10 \mathrm{~mL}$ aliquot was removed from the supernatant, placed in Petri dishes and oven dried at $105{ }^{\circ} \mathrm{C}$, until having a constant weight. The mass of the centrifugation residue (gel) was collected and weighed. The swelling power and solubility index was determined as follows (Equations 3 and 4):

$$
\begin{aligned}
& \mathrm{SP}\left(\mathrm{g} \times \mathrm{g}^{-1}\right)=\frac{\text { Gel mass }(\mathrm{g})}{\text { Sample mass on dry basis }(\mathrm{g})} \\
& \mathrm{SI}(\%)=\frac{\text { dry mass }(\mathrm{g})}{\text { mass of sample }(\mathrm{g}) \times 10} \times 100
\end{aligned}
$$

\subsection{Water and oil absorption capacity}

The Beuchat method (1977) was used to determine the water and oil absorption capacity of the extracted starch. A suspension of $3 \mathrm{~g}$ of starch in $30 \mathrm{~mL}$ of distilled water or in $30 \mathrm{~mL}$ of vegetable oil with density $0.92 \mathrm{~g} \cdot \mathrm{mL}^{-1}$ was initially prepared. The suspension was stirred for 5 min using a magnetic stirrer (Model 7664, Stuart Scientific, UK) at $500 \mathrm{rpm}$. The mixture was then transferred into a centrifuge for $15 \mathrm{~min}$ at $1306 \times \mathrm{g}$. The same procedure was used with soybean oil to determine the starch's ability to absorb oil. The mass of water or oil absorbed was expressed as $\mathrm{g} \cdot \mathrm{g}^{-1}$ of dry starch (Equation 5):

$$
\mathrm{AC}\left(\mathrm{g} \cdot \mathrm{g}^{-1}\right)=\frac{\mathrm{Pc}}{\mathrm{Ps}}
$$

Where AC is the absorption capacity (water or oil), Pc is the weight of the sample tube after centrifugation, and Ps is the weight of the sample tube.

\subsection{Viscoamilography}

Paste properties were determined on Brabender Viscographe (USB) Version 4.4 equipment with samples at a concentration of $35 \mathrm{~g}$ in $465 \mathrm{~mL}$ of distilled water. In this analysis, the values of pasting temperature, maximum, minimum and final viscosities and Setback or tendency to retrogradation (difference between the final and minimum viscosity) were obtained.

\subsection{Consistency of starch gels with different additives}

Starch gels at $4 \%(w / w)$ concentration were prepared with the addition of commercial salt, crystalized sugar, citric acid and emulsifier at concentrations of 2, 10, 0.3 and 3\% respectively and individually, in addition to the control sample composed only of starch according to Macena et al. (2020). The sample was in the form of a cylinder, $3 \mathrm{~cm}$ in diameter by $4 \mathrm{~cm}$ in height, and the texture was determined according to Macena et al. (2020). The gel texture profile of the starches was evaluated by 
Texture Analyzer Texture Analyzer (TA.XT.plus), and the results of the force-time curve were calculated by the Stable Micro Systems program for TPA (Texture Profile Analysis). The detailed test configurations were: $36 \mathrm{~mm}$ probe, $1.0 \mathrm{~mm} \cdot \mathrm{s}^{-1}$ pretest speed, $0.5 \mathrm{~mm} \cdot \mathrm{s}^{-1}$ test speed and $0.5 \mathrm{~mm} \cdot \mathrm{s}^{-1}$ posttest speed with $10 \mathrm{~mm}$ compression distance and a time of $5 \mathrm{~s}$ between compressions. The hardness, cohesiveness and gumminess of starch gels were evaluated. Texture analysis was performed with three repetitions and duplicates.

\subsection{Statistical analysis}

The results obtained in the texture analysis were submitted to analysis of variance (ANOVA) and the means evaluated by Dunnett test at $5 \%$ significance level. Statistical 7.0 software was used to perform statistical analysis.

\section{Results and discussion}

\subsection{Physicochemical characteristics and Yield Extraction}

Starch extracted from mango seeds presented as a light brown powder with a velvety texture and the extraction process had a yield of 53.89\%. Nawab et al. (2016) and Silva et al. (2013), found similar results for the same amount of mango, 56\% and $59.82 \%$, respectively. Jiamjariyatam (2018) obtained a yield of 55.95\% in jackfruit. These results show that the starch yield of waste is greater than conventional starch sources, such as cassava (18.00-29.33\%) (Williams et al., 2019).

The chemical composition of the seed starch are shown in Table 1.

Table 1: Chemical composition of the mango seed starch.

\begin{tabular}{c|c|c|c}
\hline Moisture (\%) & Proteins (\%) & Lipids (\%) & Ash (\%) \\
\hline $9.86 \pm 0.08$ & $3.63 \pm 0.18$ & $4.63 \pm 0.01$ & $0.03 \pm 0.01$ \\
\hline
\end{tabular}

Source: Authors.

The starch moisture content was 9.86\%, similar to that found by other authors, such as Silva et al. (2013) and Mendes et al. (2015), in mango starch of the same variety, 10.14 and 10.30\% respectively. Lima et al. (2012) analyzed obtained 7.37\% for potato starch and Macena et al. (2020) obtained moisture of 15.36\% for avocado starch. The moisture found in this study, presented value within the expected range established by Anvisa (2005). According to Anvisa, RDC N ${ }^{\circ} .263$ (2005) this value is $21 \%$ for corn starch and $18 \%$ for cassava starch (Brasil, 2005).

The ash content (0.03) was lower when compared to that reported in the literature. However, Onias and Cavalcanti (2014) obtained $0.07 \%$ of ash with the same variety of mango. Conventional starches presented higher ash contents than mango. Lima et al. (2012) found $0.96 \%$ for corn starch and Lovera et al. (2017), 2.54\% for cassava starch.

The protein content was $3.63 \%$. For mango of the same variety the percentage found was 5.60\%, according to Mendes et al. (2015), and 2.49\%, according Onias and Cavalcanti (2014). The protein content found in this study was considerably higher than those found by Lovera et al. (2017) for potato starch (0.11), and by Macena et al. (2020) for avocado seed starch, $1.97 \%$.

The lipid content was 4.63\%, similar values were found by Onias and Cavalcanti (2014) with 4.60\% and Silva et al. (2013) with $4.67 \%$ for mango starch of the same variety. However, Mendes et al. (2015) found a higher content (7.30). For other unconventional sources of starch, such as plantain and jackfruit, studied by Pelissari et al. (2012) and Jiamjariyatam (2018), $0.02 \%$ and $0.03 \%$ were found respectively.

The apparent amylose content found in this research was $46.77 \%$, which can be classified as high amylose starch. In the literature, a wide variation in amylose content has been reported for different starches (Kaur \& Singh, 2016). Lemos et al. 
(2018) reported amylose percentages of 19.7, 20.46, 16.36 and $11.19 \%$ in native corn, potato, banana and cassava starches, respectively, lower than the values obtained in the present study. Builders et al. (2010), Santos et al. (2017) and Macena et al. (2020) found levels of $32.5 \%, 21.5 \%$ and $30.41 \%$ respectively for avocado seed native starch amylose. Amylose content may vary according to plant age, variety or methodology applied, this may justify the variation between the cited values.

The amylose portion of starch affects viscosity and swelling, the amylose content along with other components present can affect the starch paste properties (Bello-Pérez et al., 2006). The increase in amylose content favors the increase in viscosity. The linear chains of amylose are formed of long segments forming double helices, resulting in a large number of tangles and, consequently, favoring an increase in the starch viscosity (Corradini et al., 2005). The swelling power indicates the hydration capacity of the starch. Comparing native starches with different levels of amylose, it is noted that the swelling power of low amylose starch is superior to medium and high amylose starches, because, due to the interaction between amylose molecules after retrogradation, it occurs an increase in the strength of intramolecular binding, increasing the resistance of the granules (Zavareze et al., 2009).

\subsection{Morphological characteristics of mango seed starch granules}

The size and shape of the natural starch granules are distinct among plant species and with the degree of maturity, due to the organization of the granules in crystalline zones alternated by semi-crystalline zones (Silva et al., 2013). Scanning electron microscopy images for starch extracted can be analyzed in Figure1.

Figure 1: Illustrative image of scanning electron microscope (SEM) of the starch extracted from the mango seed (Mangifera indica L.) Tommy Atkins variety - magnification 750x (A); 4000x (B).

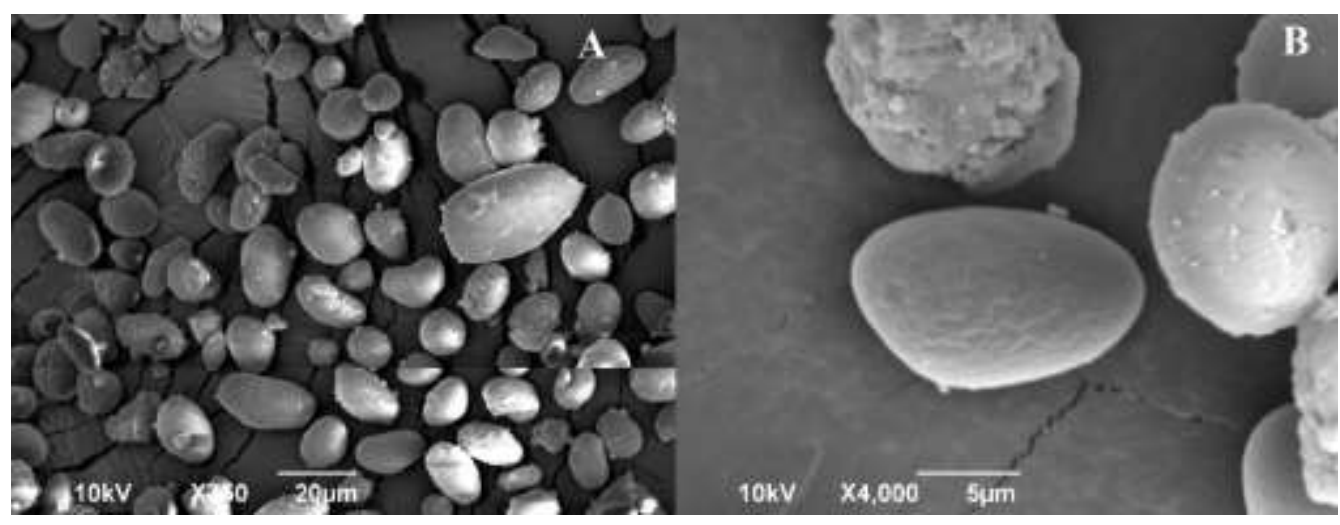

Source: Authors.

Starch granules showed predominance of spherical to irregular ellipsoidal shapes and different sizes (Fig.1A). The granule size distribution varied from 11.4 to $59 \mu \mathrm{m}$, with a predominance in the range of $20 \mu \mathrm{m}$. Granule surface is smooth with some grooves as seen in Fig.1B, the grooves were probably caused by the extraction method. Silva et al. (2013) reported the same characteristics from the same botanical source. Schmidt et al. (2019), when analyzing cassava starch, found more rounded shapes and smoother surfaces.

The absolute density found was $1.48 \pm 0.01 \mathrm{~g} \cdot \mathrm{mL}^{-1}$. Zhang et al. (2018) studying starch extracted from seed from nine different species of jackfruit in China, found density values ranging from 1.42 to $1.46 \mathrm{~g} \cdot \mathrm{mL}^{-1}$. Builders et al. (2010) found a density of $1.53 \pm 0.05 \mathrm{~g} \cdot \mathrm{mL}^{-1}$ and Macena et al. (2020) $1.47 \pm 0.03\left(\mathrm{~g} \cdot \mathrm{mL}^{-1}\right)$ both in avocado seeds. 
The density economically influences the choice of the starch extraction, decanting or centrifugation process, as the higher the starch density, the shorter the retention time in decanters and / or centrifuges. Also through density, the specific volume of starch is calculated, which is useful for dimensioning packaging and equipment in industry (Zhang et al., 2018).

\subsection{X-Ray Diffraction (XRD)}

Starch analyzed found higher Bragg peaks, around $2 \theta=15,17,18,24^{\circ}$, with A-type crystallinity, as shown in Figure 2. Starches with A-type crystalline pattern are characterized by having a high degree of chain packaging, but having a crystalline structure with superficial pores, which makes them vulnerable to attacks by acids and enzymes. Cereal starches are the main representatives of A-type crystallinity (Kim et al., 2015).

Figure 2: X-ray Diffractogram of starch extracted from the mango seed (Mangifera indica L.) Tommy Atkins variety.

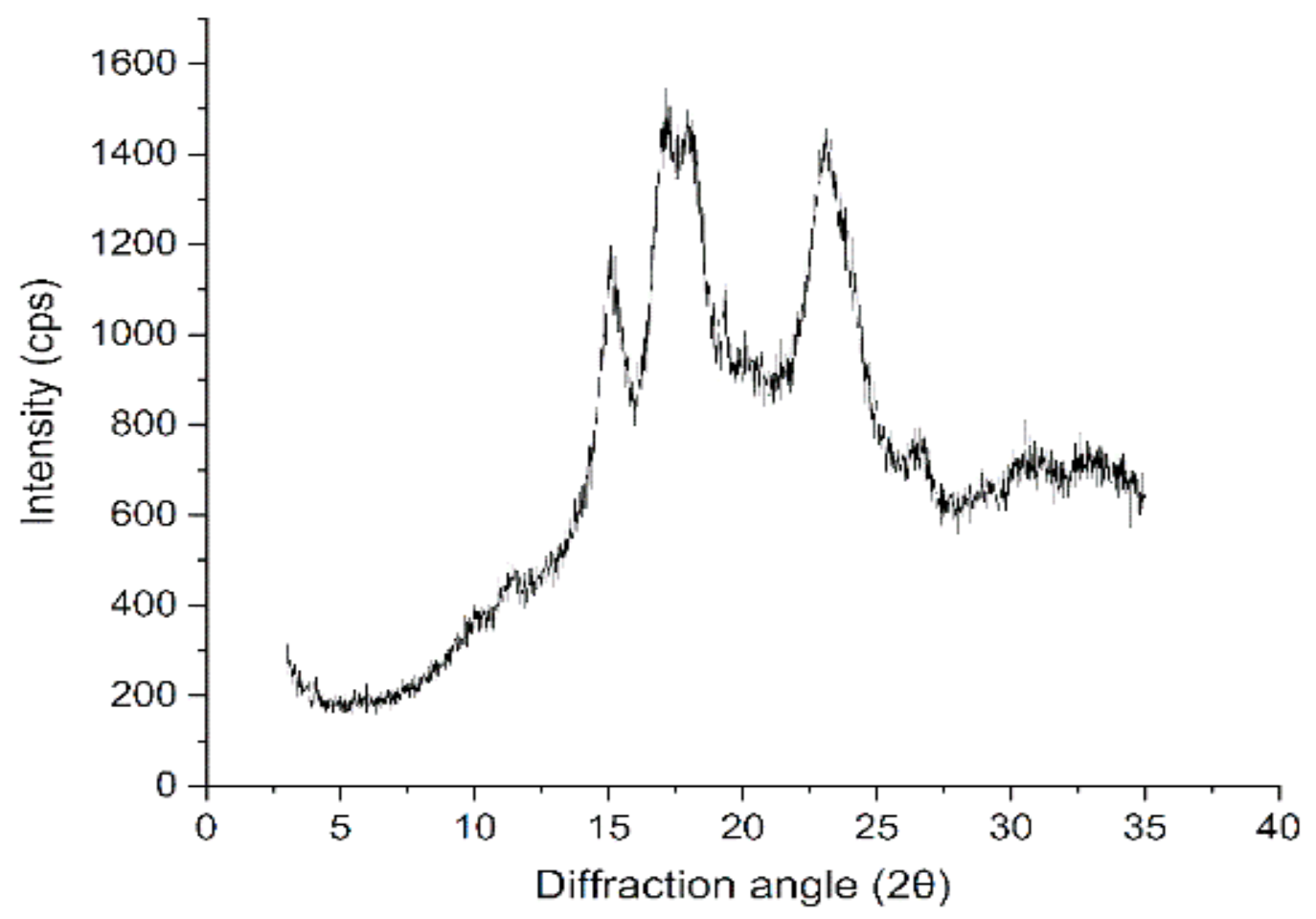

Source: Authors.

This same result was corroborated by Lima et al. (2012) when studying mango seed starch. Bet et al. (2018), when analyzing amaranth, and Lima et al. (2014), jackfruit and pitanga, found crystallinity type A. The degree of crystallinity was 54.74\%, higher than the value found by Do Prado Cordoba et al. (2016), 22.58\% for pine nut starch, and Santos et al. (2017), with avocado starch $(25.7 \%)$.

Amylose content, crystal size and amount of crystalline regions may affect the degree of crystallinity (Pascoal et al., 2013). Jiamjariyatam (2018), when studying the effects of amylose content on degree of crystallinity in jackfruit starch, concluded that with increasing amylose content crystallinity also increases, causing more crispness and less oil absorption in fried products. 


\subsection{Paste clarity and retrogradation tendency}

The study of the effect of the storage period on the transparency of the gel revealed that the starch stored for 9 days at $30{ }^{\circ} \mathrm{C}$ did not have its transmittance changed, averaging $6.72 \% \pm 0.02$. The transparency of the paste is related to light scattering resulting from the association of amylose and other components within the starch, such as fibers, lipids and pigments. In addition, opaque pastes have a more organized granular structure, with greater association between chains, which hinders the passage of light (Waterschoot et al., 2015). Compared to other conventional starch sources, the mango seed starch presented lower transmittance than corn, wheat, cassava and potato starches, $19.5 ; 13.5 ; 50.6$ and $42.2 \%$ respectively, reported by Nuwamanya et al. (2011).

In general, starches that tend to retrograde increase opacity during storage and, therefore, retrogradation is determined by measuring the transmittance of starch gel in refrigerated storage (Marcon et al., 2007). Lower opacity implies a higher \% transmittance, which suggests that starches with higher transmittance are less susceptible to retrogradation (Muccillo, 2009).

\subsection{Swelling power (SP) and Solubility Index (SI)}

The starch analyzed had a SP value $(10.51 \mathrm{~g} / \mathrm{g})$ and SI of $38.9 \%$ at $90{ }^{\circ} \mathrm{C}$. This value is far from that reported by Lin et al. (2016), with SP of $21.90 \mathrm{~g} \cdot \mathrm{g}^{-1}$ and SI of $20.30 \%$ at $95^{\circ} \mathrm{C}$ for native corn starch, and by Chel-Guerrero et al. (2016), with SP of 28-30 g. $\mathrm{g}^{-1}$ and SI of $19-20 \%$ at $90{ }^{\circ} \mathrm{C}$ for avocado seed starch. Macena et al. (2020) found lower SP (7.68 $\left.\mathrm{g} \cdot \mathrm{g}^{-1}\right)$ and SI (2.17\%) values than the present study. De Castro et al. (2019), in a recent study, found SP of $6.59 \mathrm{~g} \cdot \mathrm{g}^{-1}$ and SI of $1.60 \%$ in pitomba starch.

The SP and SI increased as a function of temperature rise, as shown in Fig.3. Water absorption patterns show that its granules do not swell appreciably at temperatures below $70{ }^{\circ} \mathrm{C}$. The starch presented higher SP at temperatures above $70{ }^{\circ} \mathrm{C}$, which suggests the beginning of paste formation.

Figure 3: Swelling power ( $\mathbf{\square})$ and solubility index $(\boldsymbol{\Delta})$ as a function of temperature for starch extracted from mango seed.

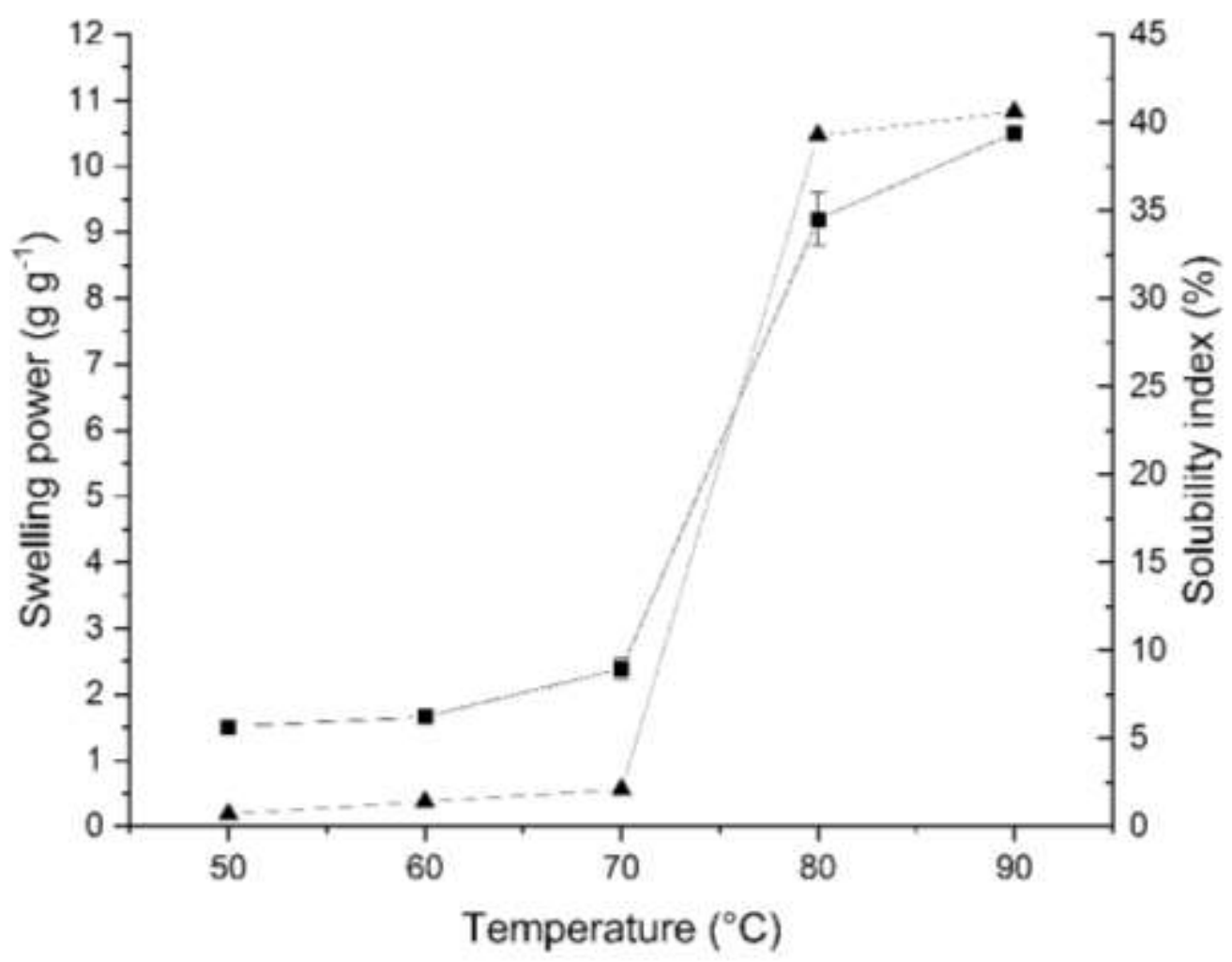


Source: Authors.

The swelling power (PI) indicates the ability of starch to hydrate under specific cooking conditions. This functional property of starch is extremely important in its form of application, because the choice of starch for a particular type of use is based on its properties (Fonseca \& Bassinello, 2016). Increase in swelling power with temperature is a result of increase in mobility of starch molecules, which facilitate the entry of water and, consequently, increase the swelling (Lawal \& Adebowale, 2005). The swelling of the granules and the solubilization of amylose and amylopectin induce the gradual loss of granular integrity with the generation of a viscous paste. When these molecules begin to reassociate favoring a more orderly structure, it is called the retrogradation process (Cereda, 2002).

Retrogradation is associated with high molecular re-association during cooling and storage, causing more water molecules to be released (Ai \& Jane, 2018). Starches with reduced swelling power are interesting for applications in foods that require greater stability (Zavareze et al., 2009), such as frozen foods for example.

\subsection{Water and oil absorption capacity}

The capacity of oil absorption (2.93 g.g $\left.\mathrm{g}^{-1} \pm 0.26\right)$ was higher than water $\left(1.19 \pm 0.15 \mathrm{~g} \cdot \mathrm{g}^{-1}\right)$. This result was expected, due to the high lipid content $(4.63 \%)$ present in the studied starch. In general, the water absorption capacity depends on the crystalline and amorphous regions within the starch, the molecular structure and the granular size distribution as the water or oil absorption capacity is dependent on their physical entrapment in the starch structure (Wani et al., 2015). CAA is related to the hydration capacity of a protein and the ability to retain absorbed water within a protein matrix, whereas the oil absorption mechanism is mainly attributed to the hydrophobicity of protein molecules (Sánchez et al., 2009).

Mendes et al. (2015), when analyzing mango starch of the same variety, obtained higher absorption in water (0.98 g/g) than in oil $(0.59 \mathrm{~g} / \mathrm{g})$, results lower than those found in the present study. Chel-Guerreiro et al. (2016) in their analysis showed that CAA of $0.17 \mathrm{~g} / \mathrm{g}$ was obtained for corn starch in the different extraction methods analyzed.

\subsection{Viscoamilography}

Viscosity is one of the most important properties of starchy materials. The viscosity curve represents the behavior of the starch during heating and allows for an evaluation of the characteristics of the paste formed by structural modifications of starch molecules and the tendency for retrogradation to occur during cooling (Alcázar-Alay \& Meireles, 2015). The results of the maximum, minimum and final viscosity parameters as a function of time and temperature are shown in Figure4. 
Figure 4: Graph representing a viscoamylogram added to the Tommy Atkins mango sleeve assembly.

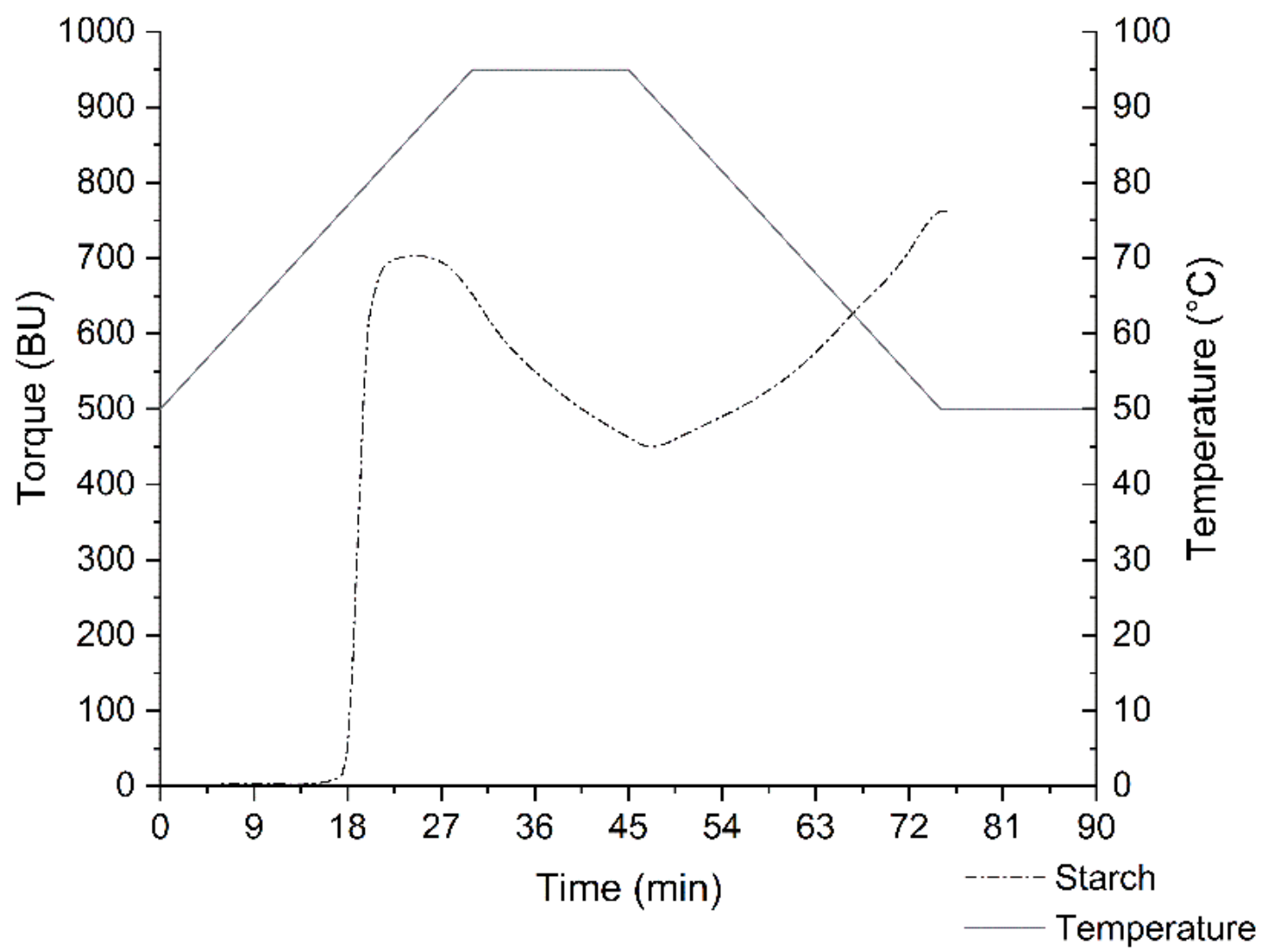

Source: Authors.

During the first $17.5 \mathrm{~min}$, the starch granules showed no change in viscosity. The pasting temperature was $75.3^{\circ} \mathrm{C}$ with initial viscosity at $16 \mathrm{BU}$, far from that reported by Chel-Guerrero et al. (2016) for corn starch $\left(76.0^{\circ} \mathrm{C}\right.$ ) and Castro et al. (2019) for pitomba starch $\left(77.5^{\circ} \mathrm{C}\right)$. The pasting temperature corresponds to that at which the starch suspension begins to increase its viscosity.

The maximum viscosity peak (viscosity peak) reading was at $706 \mathrm{BU}$ at $88.1{ }^{\circ} \mathrm{C}$ and the minimum viscosity at the constant temperature phase of $95{ }^{\circ} \mathrm{C}$ was $460 \mathrm{BU}$. The difference between maximum and minimum viscosity is called the Breakdown, which is an indication of stability of starch paste in the face of heating and mechanical shearing (Abdel-Aal et al., 2019). The final viscosity in the cooling cycle $\left(50^{\circ} \mathrm{C}\right)$ was $760 \mathrm{BU}$ and Setback (tendency to retrogradation) was $300 \mathrm{BU}$. ChelGuerrero et al. (2016) reported final viscosity of 588-598 BU and 520 BU and setback of 198 BU and 301 BU for avocado seed and maize starches, respectively. Yuan et al. (2007) reported that higher setback values are found in starches whose granules have larger diameter, due to the increased fragility found in larger granules

Lower breakdown and setback values in starches are ideal for applications as this implies, respectively, greater stability to mechanical agitation, and less tendency to retrograde them (Muccillo, 2009). Albuquerque (2012) found in his study that the setback for jackfruit seed starch (soft variety) was $954 \mathrm{cP}$, and for hard variety, $2002 \mathrm{cP}$, both therefore having a tendency to retrograde far greater than starch from mango seed from the present study.

\subsection{Consistency of starch gels with different additives}

In the unmodified form, the starch granules hydrate easily, swell quickly, break, lose viscosity and produce thin, cohesive pastes. Thus, additives are commonly used in the modification of starches in order to improve their original 
characteristics, such as promoting thickening, improve retention, increase stability, gel, disperse or confer opacity (Almeida, 2009).

The texture profile results for starch gels in the presence of different additives are shown in Table 2. The texture properties of the gels depend on the starch constituents, amylose content, shape and size of the granules, and the interaction between continuous and dispersed phases (Nishinari et al., 2013).

Table 2: Average texture profile results of starch gels added from different additives.

\begin{tabular}{|c|c|c|c|c|c|c|}
\hline \multirow[b]{2}{*}{ Parameters } & \multirow[b]{2}{*}{ Physical properties $^{2}$} & \multirow[b]{2}{*}{$\begin{array}{l}4 \% \text { native } \\
\text { starch } \\
\text { (control) }\end{array}$} & \multicolumn{4}{|c|}{ Additives; } \\
\hline & & & $\begin{array}{l}\text { Starch } \\
(4 \%)+ \\
\text { Salt } \\
(2 \%)\end{array}$ & $\begin{array}{l}\text { Starch } \\
(4 \%)+ \\
\text { Crystal } \\
\text { sugar } \\
(10 \%)\end{array}$ & $\begin{array}{l}\text { Starch } \\
(4 \%)+ \\
\text { Citric } \\
\text { acid } \\
(0.3 \%)\end{array}$ & $\begin{array}{l}\text { Starch (4\%) } \\
+ \text { emulsifier } \\
(3 \%)\end{array}$ \\
\hline Hardness (g) & $\begin{array}{c}\text { Force necessary to attain a } \\
\text { given deformation }\end{array}$ & $144.82^{a}$ & 157.40 & 129.69 & $156.33^{a}$ & $130.78^{a}$ \\
\hline Cohesiveness $^{1}$ & $\begin{array}{c}\text { Extent to which a material } \\
\text { can be deformed before it } \\
\text { ruptures. }\end{array}$ & $0.84^{a}$ & $0.84^{a}$ & $0.84^{a}$ & 0.73 & $0.84^{a}$ \\
\hline Gumminess (g) & $\begin{array}{l}\text { Energy required to } \\
\text { disintegrate a semi-solid } \\
\text { food to a state ready for } \\
\text { swallowing; a product of } \\
\text { a low degree of hardness } \\
\text { and a high degree of } \\
\text { cohesiveness. }\end{array}$ & $121.66^{\mathrm{a}}$ & $132.21^{\mathrm{a}}$ & 109.34 & $114.44^{\mathrm{a}}$ & $110.12^{\mathrm{a}}$ \\
\hline
\end{tabular}

Averages not marked with the letter (a) are significantly different from the control average at the 5\% probability level by Dunnett's test. ${ }^{1}$ Measurement admensional. ${ }^{2}$ Adapted from Civille and Szczesniak (1973). Source: Authors.

There was an increase in hardness of $8.7 \%$ of the gel after adding sodium chloride $2 \%$, followed by a decrease of $10.45 \%$ in the presence of crystalized sugar $10 \%$. For citric acid and emulsifier there was no significant difference $(p>0.05)$ for hardness.

The hardness of the gel is mainly caused by starch retrogradation, which is associated with water loss (syneresis) and the crystallization of amylopectin, making the gel harder (Zavareze et al., 2010). According to Oliveira filho and Mancim (2009), the anions present in saline solutions are considered gelatinizing agents causing the rupture of hydrogen bonds and greater swelling of the granules, providing greater amylose and amylopectin leaching, and providing greater retrogradation and syneresis. Sugars reduce the strength of the gel by binding water molecules, interfering with the formation of the gel network structure (Li et al., 2015; Wang et al., 2016).

For the cohesiveness, there was a significant difference $(\mathrm{p}<0.05)$ for citric acid additive, with a decrease of $13.1 \%$. For the other additives, salt, sugar and emulsifier, there was no significant difference $(p>0.05)$. Cohesiveness is the strength of the internal bonds that make up the body of the product, that is, the extent to which the material can be distended before breaking irreversibly (Pereira et al., 2011; Yildiz et al., 2013). 
According to Guerreiro and Meneguelli (2009), the acid $\mathrm{H}^{+}$breaks the glycosidic bonds between the starch in the solution. This means that the addition of citric acid reduces the strength of the bonds in the gel, breaking more easily, and forming less firm gels.

Gumminess values showed that it differed significantly $(\mathrm{p}<0.05)$ only for the sucrose additive, with a decrease of $10.1 \%$. According to Ramos and Gomide (2007), the gumminess is defined by the energy needed to disintegrate the food to a ready-toswallow state.

A study by Zavareze et al. (2010), in rice starch gels concluded that the higher the starch amylose content, the greater the force required for gel disintegration. The apparent amylose content found in this research was (46.77\%), so it can be classified as a high amylose starch. On the other hand, according Li et al. (2015) and Wang et al. (2016), sugar reduces the strength of the gel by binding water molecules and interfering with the formation of the gel network structure, consequently the presence of sugar reduces the gumminess of the gel.

\section{Conclusions}

The Tommy Atkins mango seed starch (Mangifera indica L.) has potential for use as an unconventional starch raw material in food systems. In addition to an excellent extraction yield (53.89\%), the use of this by-product favors the intelligent use of mango-pulp agroindustry residues, avoiding damage to the environment, in addition to contributing to food safety and reducing the use of starches from food sources such as corn, potatoes and cassava.

The starch presented desirable characteristics even in its natural form. It can be considered as an alternative for the preparation of food products such as dehydrated soups since it has low gel formation temperature, and in meat products because it has good water holding capacity. Also, due to high amylose content and good crystallinity, it can also be used in fried products as it causes higher crispness and less oil absorption.

Mango seed starch therefore constitutes a potential starch source for future studies and applications in foods. The extraction of the starch in question would also increase the promotion of mango cultivation in the State of Bahia, which was the second largest mango producer in Brazil in 2019 according to Serviço Nacional de Aprendizagem Rural. (http://www.sistemafaeb.org.br/noticias/detalhe/noticia/cultivo-de-manga-e-destaque-no-norte-da-bahia-estado-e-o-2o-maiorprodutor-de-frutas-do-pais/, retrieved on December 07, 2020).

\section{Acknowledgments}

The authors are thankful to the State University of Feira de Santana (UEFS) and Federal University of Bahia (UFBA) for the academic support, and the Fundação de Amparo à Pesquisa do Estado da Bahia (FAPESB) for the financial support.

\section{References}

Abdel-Aal, E. S. M., Rabalski, I., Hernandez, M., L’Hocine, L., Patterson, C. A., \& Hucl, P. (2019). Effect of sodium chloride, sucrose, and xanthan gum on pasting properties and gel syneresis of hairless canary seed starch. Cereal Chemistry, 96(5), 908-919.

Adebowale, K. O., Afolabi, T. A., \& Lawal, O. S. (2002). Isolation, chemical modification and physicochemical characterisation of Bambarra groundnut (Voandzeia subterranean) starch and flour. Food chemistry, 78(3), 305-311.

Ai, Y., \& Jane, J. L. (2018). Understanding starch structure and functionality. In Starch in food (pp. 151-178). Woodhead Publishing.

Albuquerque, F. S. M. D. (2012). Estudo das características estruturais e das propriedades funcionais do amido de sementes de jaca (ArtocarpusheterophylusLam) variedades mole e dura.

Alcázar-Alay, S. C., \& Meireles, M. A. A. (2015). Physicochemical properties, modifications and applications of starches from different botanical sources. Food Science and Technology, 35(2), 215-236. 
Almeida, L. F. (2009). Amidos: Fontes, estruturas e propriedades funcionais. Aditivos Ingredientes, 63, 27-41.

Andrade, M. M. P., de Oliveira, C. S., Colman, T. A. D., da Costa, F. J. O. G., \& Schnitzler, E. (2014). Effects of heat-moisture treatment on organic cassava starch. Journal of Thermal Analysis and Calorimetry, 115(3), 2115-2122.

AOAC. 2005. Official Methods of Analysis of The Association of Official Analytical Chemist, Inc.

Azevêdo, L. C., Azoubel, P. M., Silva, I. R. A., Araújo, A. D. B., \& de Oliveira, S. B. (2008). Caracterização físico-química da farinha da casca de manga cv. Tommy atkins. In Embrapa Semiárido-Artigo em anais de congresso (ALICE). In: Congresso Brasileiro de Ciência e Tecnologia de Alimentos, 21; Seminário Latino Americano e do Caribe de Ciência e Tecnologia de Alimentos, 15, 2008, Belo Horizonte. Ciência e inovação para o desenvolvimento sustentável. Belo Horizonte: SBCTA, 2008.

Bello-Pérez, L. A., García-Suárez, F. J., Méndez-Montealvo, G., Oliveira do Nascimento, J. R., Lajolo, F. M., \& Cordenunsi, B. R. (2006). Isolation and characterization of starch from seeds of Araucaria brasiliensis: a novel starch for application in food industry. Starch-Stärke, 58(6), $283-291$.

Beninca, C., Colman, T. A. D., Lacerda, L. G., Carvalho Filho, M. A. S., Bannach, G., \& Schnitzler, E. (2013). The thermal, rheological and structural properties of cassava starch granules modified with hydrochloric acid at different temperatures. Thermochimica Acta, 552, 65-69.

Bet, C. D., de Oliveira, C. S., Colman, T. A. D., Marinho, M. T., Lacerda, L. G., Ramos, A. P., \& Schnitzler, E. (2018). Organic amaranth starch: a study of its technological properties after heat-moisture treatment. Food chemistry, 264, 435-442.

Beuchat, L. R. (1977). Functional and electrophoretic characteristics of succinylated peanut flour protein. Journal of Agricultural and Food chemistry, 25(2), $258-261$.

Brasil. Resolução ANV n²63. 22, de 15 de setembro de 2005. Regulamento Técnico ara produtos de Cereais Procedimentos e Farelos. Diário Oficial da União, Brasília, DF, 16 set. 2005 .

Builders, P. F., Nnurum, A., Mbah, C. C., Attama, A. A., \& Manek, R. (2010). The physicochemical and binder properties of starch from Persea americana Miller (Lauraceae). Starch-Stärke, 62(6), 309-320.

Castanha, N., Villar, J., da Matta Junior, M. D., dos Anjos, C. B. P., \& Augusto, P. E. D. (2018). Structure and properties of starches from Arracacha (Arracacia xanthorrhiza) roots. International journal of biological macromolecules, 117, 1029-1038.

Castro, D. S., dos Santos Moreira, I., de Melo Silva, L. M., Lima, J. P., da Silva, W. P., Gomes, J. P., \& de Figueirêdo, R. M. F. (2019). Isolation and characterization of starch from pitomba endocarp. Food Research International, 124, 181-187.

Cereda, M. P. (2002). Propriedades gerais do amido. FUNDAÇÃO CARGILL. Culturas de tuberosas amiláceas Latino Americanas.

Chel-Guerrero, L., Barbosa-Martín, E., Martínez-Antonio, A., González-Mondragón, E., \& Betancur-Ancona, D. (2016). Some physicochemical and rheological properties of starch isolated from avocado seeds. International journal of biological macromolecules, 86, $302-308$.

Civille, G. V., \& Szczesniak, A. S. (1973). Guidelines to training a texture profile panel. Journal of texture studies, 4(2), $204-223$.

Colman, T. A. D., Demiate, I. M., \& Schnitzler, E. (2014). The effect of microwave radiation on some thermal, rheological and structural properties of cassava starch. Journal of Thermal Analysis and Calorimetry, 115(3), 2245-2252.

Corradini, E., Lotti, C., Medeiros, E. S. D., Carvalho, A. J., Curvelo, A. A., \& Mattoso, L. H. (2005). Estudo comparativo de amidos termoplásticos derivados do milho com diferentes teores de amilose. Polímeros, 15(4), 268-273.

De Castro, D. S., dos Santos Moreira, I., de Melo Silva, L. M., Lima, J. P., da Silva, W. P., Gomes, J. P., \& de Figueirêdo, R. M. F. (2019). Isolation and characterization of starch from pitomba endocarp. Food Research International, 124, 181-187.

Do Prado Cordoba, L., Ribeiro, L. S., Rosa, L. S., Lacerda, L. G., \& Schnitzler, E. (2016). Effect of enzymatic treatments on thermal, rheological and structural properties of pinhão starch. Thermochimica Acta, 642, 45-51.

Fonseca, R. C., \& Bassinello, P. Z. (2016). Poder de Inchamento e Microscopia Eletrônica de Varredura de Diferentes Genótipos de Arroz de Terras Altas. Revista Processos Químicos, 10(20), 333-338.

Guerreiro, L. M. R., \& Meneguelli, F. C. (2009). Heat treatment and acidity influence on the rheological behavior of commercial organic waxy corn starch. Food Science and Technology, 29(2), 412-419.

Jiamjariyatam, R. (2018). Effect of Jackfruit Seed Starch (Artocarpus heterophyllus) Microstructure on Properties and Characteristics of Fried Battered Product. Walailak Journal of Science and Technology (WJST), 15(12), 879-892.

Kaur, M., \& Singh, S. (2016). Physicochemical, morphological, pasting, and rheological properties of tamarind (Tamarindus indica L.) kernel starch. International Journal of Food Properties, 19(11), 2432-2442.

Lawal, O. S., \& Adebowale, K. O. (2005). Physicochemical characteristics and thermal properties of chemically modified jack bean (Canavalia ensiformis) starch. Carbohydrate Polymers, 60(3), 331-341.

Lemos, P. V. F., Barbosa, L. S., Ramos, I. G., Coelho, R. E., \& Druzian, J. I. (2018). The important role of crystallinity and amylose ratio in thermal stability of starches. Journal of Thermal Analysis and Calorimetry, 131(3), 2555-2567.

Li, Q., Zhang, L., Ye, Y., \& Gao, Q. (2015). Effect of salts on the gelatinization process of Chinese yam (Dioscorea opposita) starch with digital image analysis method. Food Hydrocolloids, 51, 468-475. 
Lima, B. N., Cabral, T. B., C Neto, R. P., Tavares, M. I. B., \& Pierucci, A. P. T. (2012). Estudo do amido de farinhas comerciais comestíveis. Polímeros, 22(5), 486-490.

Lima, B. N. B., Lima, F. F., Tavares, M. I. B., Costa, A. M. M., \& Pierucci, A. P. T. R. (2014). Determination of the centesimal composition and characterization of flours from fruit seeds. Food Chemistry, 151, 293-299.

Lin, L., Guo, D., Zhao, L., Zhang, X., Wang, J., Zhang, F., \& Wei, C. (2016). Comparative structure of starches from high-amylose maize inbred lines and their hybrids. Food Hydrocolloids, 52, 19-28.

Lovera, M., Pérez, E., \& Laurentin, A. (2017). Digestibility of starches isolated from stem and root tubers of arracacha, cas sava, cush-cush yam, potato and taro. Carbohydrate polymers, 176, 50-55.

Macena, J. F. F., Souza, J. C. A. D., Camilloto, G. P., \& Cruz, R. S. (2020). Physico-chemical, morphological and technological properties of the avocado (Persea americana Mill. cv. Hass) seed starch. Ciência e Agrotecnologia, 44.

Marcon, M. J. A., Avancini, S. R. P., \& Amante, E. R. (2007). Propriedades químicas e tecnológicas do amido de mandioca e do polvilho azedo.

Mendes, M. L. M., Ribeiro, A. P. L., \& Almeida, E. C. (2015). Efeito da acidificação nas propriedades físico-químicas e funcionais do amido de sementes de manga (Mangifera indica L.), variedade Tommy Atkins. Revista Ceres, 62(3), 225-232.

Muccillo, R. C. S. T. (2009). Caracterização e avaliação de amido nativo e modificado de pinhão mediante provas funcionais e térmicas. Lume-UFRS, Porto Alegre-RS.

Nawab, A., Alam, F., Haq, M. A., \& Hasnain, A. (2016). Biodegradable film from mango kernel starch: Effect of plasticizers on physical, barrier, and mechanical properties. Starch-Stärke, 68(9-10), 919-928.

Nishinari, K., Kohyama, K., Kumagai, H., Funami, T., \& Bourne, M. C. (2013). Parameters of texture profile analysis. Food Science and Technology Research, 19(3), 519-521.

Nuwamanya, E., Baguma, Y., Wembabazi, E., \& Rubaihayo, P. (2011). A comparative study of the physicochemical properties of starches from root, tuber and cereal crops. African Journal of Biotechnology, 10(56), 12018-12030.

Oliveira Filho, J. H., \& Mancim, A. C. (2009). Aditivos e ingredientes e seus reflexos sobre as propriedades viscoamilográficas de amido de milho. Brazilian Journal of Food Technology, 11, 78-84.

Onias, E. A., \& Cavalcanti, M. T. (2014). Obtenção e caracterização do amido do endocarpo da manga Tommy Atkins proveniente do resíduo agroindustrial. Revista Verde de Agroecologia e Desenvolvimento Sustentável, 9(5), 60-63.

Pascoal, A. M., Di-Medeiros, M. C. B., Batista, K. A., Leles, M. I. G., Lião, L. M., \& Fernandes, K. F. (2013). Extraction and chemical characterization of starch from S. lycocarpum fruits. Carbohydrate polymers, 98(2), 1304-1310.

Pelissari, F. M., Yamashita, F., Garcia, M. A., Martino, M. N., Zaritzky, N. E., \& Grossmann, M. V. E. (2012). Constrained mixture design applied to the development of cassava starch-chitosan blown films. Journal of Food Engineering, 108(2), 262-267.

Pereira, A. G. T., Ramos, E. M., Teixeira, J. T., Cardoso, G. P., Ramos, A. D. L. S., \& Fontes, P. R. (2011). Effects of the addition of mechanically deboned poultry meat and collagen fibers on quality characteristics of frankfurter-type sausages. Meat science, 89(4), 519-525.

Ramos, E. M., \& de Miranda Gomide, L. A. (2007). Avaliação da qualidade de carnes: fundamento e metodologias. UFV.

Sánchez, T., Salcedo, E., Ceballos, H., Dufour, D., Mafla, G., Morante, N., \& Moreno, I. X. (2009). Screening of starch quality traits in cassava (Manihot esculenta Crantz). Starch-Stärke, 61(1), 12-19.

Santos, D. M., Ascheri, D. P. R., de Lacerda Bukzem, A., Morais, C. C., Carvalho, C. W. P., \& Ascheri, J. L. R. (2017). Physicochemical properties of starch from avocado seed (Persea Americana Mill). Boletim do Centro de Pesquisa de Processamento de Alimentos, 34(2).

Schmidt, V. C. R., Blanco-Pascual, N., Tribuzi, G., \& Laurindo, J. B. (2019). Effect of the degree of acetylation, plasticizer concentration and relative humidity on cassava starch films properties. Food Science and Technology, 39(2), 491-499.

Schoch, T. J., \& Leach, W. (1964). Determination of absolute density; liquid displacement. Methods in carbohydrate chemistry, 4, $101-103$.

Silva, G. A., Cavalcanti, M. T., Almeida, M. C. D. M., Araújo, A. D. S., Chinelate, G. C., \& Florentino, E. R. (2013). Utilização do amido da amêndoa da manga Tommy Atkins como espessante em bebida láctea. Revista Brasileira de Engenharia Agrícola e Ambiental, 17(12), 1326-1332.

Vieira, P. A. F., de Queiroz, J. H., Vieira, B. C., Mendes, F. Q., de Almeida Barbosa, A., Muller, E. S., \& de Moraes, G. H. K. (2009). Chemical characterization of agroindustrial residue of mango (Mangifera indica L.) variety Uba/Caracterizacao quimica do residuo do processamento agroindustrial da manga (Mangifera indica L.) var. Uba. Alimentos e Nutricao (Brazilian Journal of Food and Nutrition), 20(4), 617-624.

Wang, L., Xu, J., Fan, X., Wang, Q., Wang, P., Zhang, Y., \& Yu, Y. (2016). Effect of disaccharides of different composition and linkage on corn and waxy corn starch retrogradation. Food Hydrocolloids, 61, 531-536.

Wani, I. A., Sogi, D. S., Shivhare, U. S., \& Gill, B. S. (2015). Physico-chemical and functional properties of native and hydrolyzed kidney bean (Phaseolus vulgaris L.) protein isolates. Food Research International, 76, 11-18.

Waterschoot, J., Gomand, S. V., Fierens, E., \& Delcour, J. A. (2015). Production, structure, physicochemical and functional properties of maize, cassava, wheat, potato and rice starches. Starch-Stärke, 67(1-2), 14-29. 
Research, Society and Development, v. 10, n. 3, e30310310118, 2021

(CC BY 4.0) | ISSN 2525-3409 | DOI: http://dx.doi.org/10.33448/rsd-v10i3.10118

Williams, G., Ansah, K. O., Agbenorhevi, J. K., Oduro, I. N., \& Bobobee, E. (2019). Characterization of starch from New Cassava accessions at different maturity.

Yildiz, Ö., Yurt, B., Baştürk, A., Toker, Ö. S., Yilmaz, M. T., Karaman, S., \& Dağlıŏlu, O. (2013). Pasting properties, texture profile and stress-relaxation behavior of wheat starch/dietary fiber systems. Food Research International, 53(1), 278-290.

Yuan, Y., Zhang, L., Dai, Y., \& Yu, J. (2007). Physicochemical properties of starch obtained from Dioscorea nipponica Makino comparison with other tuber starches. Journal of food engineering, 82(4), 436-442.

Zavareze, E. D. R., Pereira, J. M., Moura, F. A., Spier, F., Helbig, E., \& Dias, A. (2010). Teor de amido resistente e perfil de textura de amidos de arroz com diferentes níveis de amilose modificados hidrotermicamente. Brazilian Journal of Food Technology, 13(4), 96-101.

Zavareze, E. R., Rodrigues, A. O., Storck, C. R., Assis, L. M., Wally, A. P. S., \& Dias, A. R. G. (2009). Poder de inchamento e solubilidade de amido de arroz submetido ao tratamento térmico com baixa umidade. Brazilian Journal of Food Technology, 31-35.

Zhang, Y., Hu, M., Zhu, K., Wu, G., \& Tan, L. (2018). Functional properties and utilization of Artocarpus heterophyllus Lam seed starch from new species in China. International journal of biological macromolecules, 107, 1395-1405. 